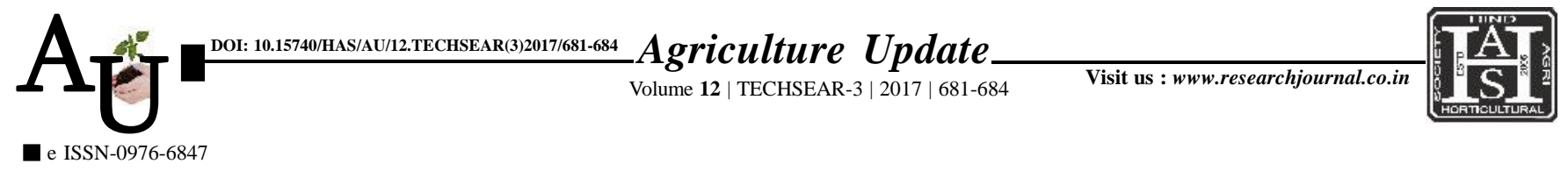

\title{
Research Article: Biology of cotton pink bollworm, Pectinophora gossypiella (Saunders) Lepidoptera: Gelechiidae
}

Article Chronicle:

Received :

10.07.2017;

Accepted :

25.07.2017

KeY Words:

Pink bollworm,

Biology, Varied

temperature regimes

\section{P. SAPNA, M. BHEEMANNA, A.C. HOSAMANI, V.N. GHANTE AND B. KISAN}

SUMMARY : The biology of Pectinophora gossypiella was studied at three different temperature regimes of viz., $25 \pm 1,30 \pm 1$ and $35 \pm 1^{\circ} \mathrm{C}$. The study revealed that the time taken for developmental stages was less with increase in temperature. At $25 \pm 1{ }^{\circ} \mathrm{C}$, the incubation period, larval period and pupal period were $3.77 \pm 0.78$ days, $23.15 \pm 3.23$ days and $8.75 \pm 0.55$ days, respectively. While at $35 \pm 1{ }^{\circ} \mathrm{C}$, the incubation period,larval period and pupal period were comparatively low ( $1.95 \pm 0.51$ days, $12.8 \pm 1.96$ days and $5.20 \pm 0.47$ days, respectively).The longevity of adult male was $9.00 \pm 0.5$ days at $25 \pm 1{ }^{\circ} \mathrm{Cand}$ $3.57 \pm 0.4$ days at $35 \pm 1^{\circ} \mathrm{C}$, whereas female longevity was $9.5 \pm 1.0$ days at $25 \pm 1^{\circ} \mathrm{C}$ and $3.45 \pm 0.6$ days at $35 \pm 1{ }^{\circ} \mathrm{C}$. The total life cycle from egg to adult emergence was high at $25 \pm 1{ }^{\circ} \mathrm{C}(52.3 \pm 6.51$ days $)$ and low at $35 \pm 1{ }^{\circ} \mathrm{C}(29.8 \pm 4.28$ days). The oviposition period was ranged from 1.5 to 2.5 at different temperature but the fecundity was high $(112.85 \pm 16.1 \mathrm{eggs} / \mathrm{female})$ at $25 \pm 1^{\circ} \mathrm{C}$ and less $(49.80 \pm 8.69$ eggs/female) at $35 \pm 1{ }^{\circ} \mathrm{C}$.The influence of decreasing in temperature was evident in extending the duration of the life cycle.

How to cite this article : Sapna, P., Bheemanna, M., Hosamani, A.C., Ghante, V.N. and Kisan, B. (2017). Biology of cotton pink bollworm, Pectinophora gossypiella (Saunders) Lepidoptera: Gelechiidae. Agric. Update, 12(TECHSEAR-3) : 681-684; DOI: 10.15740/HAS/AU/12.TECHSEAR(3)2017/681-684.
Author for correspondence :

\section{P. SAPNA}

Main Agricultural Research Station and College of Agriculture, (U.A.S.), RAICHUR (KARNATAKA) INDIA Email : sapna4854@ gmail.com

See end of the article for authors' affiliations 